\title{
Responses of diploid and triploid Pacific oysters Crassostrea gigas to Vibrio infection in relation to their reproductive status
}

\author{
S. De Decker ${ }^{\mathrm{a}}$, J. Normand ${ }^{\mathrm{a}}$, D. Saulnier ${ }^{\mathrm{a}}$, F. Pernet $^{\mathrm{b}}$, S. Castagnet ${ }^{\mathrm{a}}$ and P. Boudry $^{\mathrm{c},{ }^{*}}$ \\ ${ }^{a}$ Ifremer, Laboratoire de Génétique et Pathologie, Ave. Mus de Loup, Ronce-Les-Bains, 17390 La \\ Tremblade, France \\ ${ }^{\mathrm{b}}$ Ifremer, Laboratoire Environnement Ressources Languedoc-Roussillon, Pôle Mer et Lagunes, Bd \\ Jean Monnet, BP 171, 34203 Sète Cedex, France \\ ${ }^{\mathrm{C}}$ Ifremer, Laboratoire de Physiologie des Invertébrés, Technopôle Brest Iroise, BP 70, 29280 \\ Plouzané, France \\ *: Corresponding author : P. Boudry, email address: Pierre.Boudry@ifremer.fr
}

\begin{abstract}
:
Several Vibrio species are known to be pathogenic to the Pacific oyster Crassostrea gigas. Survival varies according to pathogen exposure and high mortality events usually occur in summer during gametogenesis. In order to study the effects of gametogenetic status and ploidy (a factor known to affect reproduction allocation in oysters) on vibriosis survival, we conducted two successive experiments. Our results demonstrate that a common bath challenge with pathogenic Vibrio splendidus and Vibrio aestuarianus on a mixture of mature, spawning and non-mature oysters can lead to significant mortality. Previous bath challenges, which were done using only non-mature oysters, had not produced mortality. Immunohistochemical analyses showed the affinity of Vibrio for gonadic tissues, highlighting the importance of sexual maturity for vibriosis infection processes in oysters. Mortality rate results showed poor repeatability between tanks, however, in this bath challenge. We then tested a standardized and repeatable injection protocol using two different doses of the same combination of two Vibrio species on related diploid and triploid oysters at four different times over a year. Statistical analyses of mortality kinetics over a 6-day period after injection revealed that active gametogenesis periods correspond to higher susceptibility to vibriosis and that there is a significant interaction of this seasonal effect with ploidy. However, no significant advantage of triploidy was observed. Triploid oysters even showed lower survival than diploid counterparts in winter. Results are discussed in relation to differing energy allocation patterns between diploid and triploid Pacific oysters.
\end{abstract}

\section{Graphical abstract}

Immunohistochemistry revealed that Vibrio showed affinity for gonadic tissues. 




\section{Research highlights}

A bath challenge with pathogenic Vibrio on mature oysters led to significant mortality. Immunohistochemistry revealed that Vibrio showed affinity for gonadic tissues. Active gametogenesis periods correspond to high susceptibility to experimental vibriosis. Triploid oysters did not show higher resistance than diploid to experimental vibriosis.

Keywords: Experimental vibriosis; Crassostrea gigas; Vibrio; Survival distribution function; Triploidy; Reproductive effort 


\section{Introduction}

For many years, significant mortalities of Pacific oyster Crassostrea gigas have been reported during the summer period. These seasonal mortalities produce no specific clinical signs of disease and affect both juveniles and adults, but are usually greater among young individuals (i.e. -seed" or -spat"). This is notably the case in France, where seed mortalities have become a serious threat to the oyster industry. The aetiology of this phenomenon is clearly multifactorial, resulting from complex interactions between pathogenic agents, environmental factors and the genetic and physiological status of the oysters (Samain and McCombie, 2008). Two main types of pathogenic agents, the herpes virus OsHV-1 (Renault et al., 1995) and bacteria of the genus Vibrio (Vibrio splendidus and Vibrio aestuarianus), have been detected in dying oysters during summer mortality episodes (Garnier et al., 2007; Gay et al., 2004; Labreuche et al., 2006b; Lacoste et al., 2001; Le Roux et al., 2002; Saulnier et al., 2009). For Vibrio, a four-year epidemiological survey (2003-2007) aiming to identify bacteria pathogenic to $C$. gigas confirmed the high prevalence of Vibrio splendidus and Vibrio aestuarianus bacterial strains associated with mortality events in France (Saulnier et al., 2010). The virulence of the Vibrio strains isolated during mortality outbreaks has also been assessed using a controlled experimental infection approach (Saulnier et al., 2010).

Besides virulence of pathogenic agents, the variability of oyster physiological status, which is under the control of environmental conditions and genetic characteristics, probably explains much of the variability observed in severity of summer mortality episodes (Samain and McCombie, 2008). Indeed, allocation to each of the main physiological functions (i.e. growth, reproduction and survival) is known to covary, generating physiological and/or genetic tradeoffs (Kooijman, 2000; Stearns, 1976). Thus, high reproductive effort for C. gigas, which can account for $55 \%$ of the annual energy budget (Van der Meer, 2006), was expected to result in an increase in mortality. A reproduction-survival trade-off was demonstrated using selective breeding experiments (Beattie et al., 1980; Boudry et al., 2008; Perdue et al., 1981). The proposed explanation was that high sexual maturation activity could lead to physiological weakness (Mori, 1979), and that this would result in an immune depression (Duchemin et al., 2007; Li et al., 2009b; Pouvreau and Lepennec, 2006; Soletchnik et al., 1997). Moreover, some environmental factors are known to trigger gonadic tissue development. High food 
2005) have been shown to increase reproductive allocation. Due to the trade-off between reproductive effort and survival mentioned above, these factors have also been shown to be associated with higher summer mortality (Pouvreau et al., 2003; Soletchnik et al., 2005; Soletchnik et al., 1999; Soletchnik et al., 2007). Finally, the sign of the genetic correlations between summer survival and reproductive allocation have also been shown to vary according to food abundance (Ernande et al., 2004), demonstrating the primary importance of exogenous factors in controlling energy allocation to different physiological functions and their covariation.

In oysters, triploidy induction is the most common genetic method to enhance production yield through phenotypic improvement (Piferrer et al., 2009). Triploidy affects allocation to physiological functions in oysters and a wide-range of other species. Most importantly, triploid Pacific oysters commonly exhibit a reduced but variable reproductive effort (Normand et al., 2009) and, in parallel, exhibit faster growth than diploid individuals (Allen and Downing, 1986; Nell and Perkins, 2005). Triploid oysters have also been seen to have higher resistance to summer mortality (Boudry et al., 2008), although contradictory performances have also been reported for triploid summer survival (Cheney et al., 2000). It should, however, be noted that only a limited number of studies have examined physiological performances of triploid molluscs, meaning that little is known about actual energetic allocation to different functions. The improved growth and survival of triploid oysters has mainly been interpreted as an indirect effect of triploidy through energetic reallocation from gonadic development to somatic growth and resistance (Allen and Downing, 1986; Allen and Downing, 1990; Garnier-Géré et al., 2002). An alternative hypothesis explains the improvement of survival in triploid oysters as a result of a superior energy budget irrespective of energetic re-allocation processes (Hawkins et al., 1994)

The present study aimed to investigate the relationships between ploidy, survival and reproductive allocation, in oysters challenged with pathogenic Vibrio. First, a non-invasive experimental infection protocol coupled with specific immunohistochemical analysis was used to localize pathogenic Vibrio in oyster organs and to test for its affinity for gonadic tissue. Second, susceptibility to vibriosis and gonad development were studied over an annual reproductive cycle on related diploid and triploid oysters using a reproducible experimental co-infection protocol and two pathogenic Vibrio (V. splendidus and V.aestuarianus) (Saulnier et al., 2010). Outcomes are discussed in terms of resource allocation and life-history 
121 theory. The results offer some insight into the oyster summer mortality phenomenon and, 122 more generally, show how host-bacteria interactions can mitigate infectious diseases in 123 bivalves.

124 


\section{1. First experiment - Bath challenge and immunohistochemical analysis}

\section{1. 1. Animals studied and reproductive conditioning}

132 One-year-old diploid C. gigas oysters were purchased from natural recruitment in the Bassin de Marennes-Oléron (Charente-Maritime, France). Half of these oysters were maintained for two months indoors, using the same temperature and food availability conditions as those found in the field (Ifremer, La Tremblade). The second half of the oysters were matured for two months indoors, using controlled temperature $\left(20^{\circ} \mathrm{C}\right)$ to induce gonadic maturation. Two different sets of oysters were obtained within this second group: spawning and mature (reproductive status was checked visually). Three types of oysters were thus obtained from the common initial population: 1. spawning, 2. mature and 3. non mature animals. All oysters were maintained at $16{ }^{\circ} \mathrm{C}$ for two days before the bath challenge (described below) in order to induce spawning events in the ripe individuals when they were transferred to the experimental tanks at $20^{\circ} \mathrm{C}$.

\section{1. 2. Bath challenge}

A bath infection challenge with $V$. splendidus LGP32-GFP and $V$. aestuarianus 02/041 strains was first carried out on diploid oysters displaying contrasted sexual maturity. Groups of 3 to 5 oysters of each type (1. spawning, 2. mature, 3. non mature animals) were placed together in 10-litre tanks, after shell tagging for identification. Four tanks were set up for the bath challenge and three other tanks were prepared in the same way as an infection control. The combination of LGP32-GFP and 02/041 strains was produced by mixing suspensions of each bacterium at equal concentration (1:1 v/v), as described in Saulnier et al. (2010), and adding the mixture to the UV-treated seawater of each tank at a concentration of $10^{6} \mathrm{CFU} / \mathrm{ml}(\mathrm{CFU}$ : Colony Forming Unit) established by absorbance determination at $600 \mathrm{~nm}$ wavelength and by plate counting method on Marine Agar (Difco) using appropriate dilutions. Oysters were immerged in contaminated seawater at $18{ }^{\circ} \mathrm{C}$ for $40 \mathrm{~h}$ in non-circulating aerated conditions.

157 They were then abundantly rinsed with UV-treated seawater and transferred to new tanks 158 filled with fresh UV-treated seawater. Control oysters were treated in the same manner as 
159 bath-infected ones, replacing the Vibrio inoculum with artificial seawater. Spawning events, 160 which affected oysters at the spawning stage, were induced by thermal stress at $20^{\circ} \mathrm{C}$ in all 161 tanks; they were observed in both contaminated and control tanks 1-2 h post-transfer, with strong contractions of the oyster muscle and gametes visible in the water. Thereafter, oyster mortality was monitored daily for 2 weeks. Any dead oysters were removed from each tank

164

\section{1. 4. Statistical analysis}

\section{1. 3. Immunohistochemical analysis}

Because the LGP32-GFP mutated strain also has a gene coding chloramphenicol acetyl transferase (CAT), responsible for resistance to chloramphenicol, this last gene product was targeted to immuno-localize LGP32-GFP by immunohistochemistry. This mutant $V$. splendidus strain was provided by F. Le Roux. A commercial polyclonal sheep antibody against CAT type 1 and labelled with digoxigenin antigen was purchased from Roche. Before use, the specificity of the polyclonal antibody solution was increased by in vitro absorption on a wild LGP32 strain bacterial suspension.

A few dead mature animals sampled during bath immersion were fixed in Davidson's fluid for $24 \mathrm{~h}$ and transferred to $70 \%$ ethanol before being dehydrated in alcohol-xylene series and embedded in paraffin wax. All steps were performed at room temperature. Sections of $5 \mu \mathrm{m}$ were mounted on silane-prep slides (Sigma), dewaxed, rehydrated, and successively incubated for $30 \mathrm{~min}$ in blocking reagent (Roche) prepared in 1X Tris-buffered saline solution (TBS), $30 \mathrm{~min}$ with anti-CAT antibody $(1 \mu \mathrm{g} / \mathrm{ml})$ prepared in blocking reagent TBS solution, and 30 min with anti-Digoxigenin Fab fragments antibody conjugated with alkaline phosphatase (Roche) and diluted in TBS. Slides were washed twice with TBS between each step. Immuno-detection was performed with alkaline phosphatase chromogen BCIP-NBT (Sigma) prepared in an alkaline phosphatase buffer (Tris-base $100 \mathrm{mM} \mathrm{pH} \mathrm{9,} \mathrm{MgCl}_{2} 50 \mathrm{mM}$, 
192 A $\chi^{2}$ test was performed to analyse significant differences of survival rates obtained after the bath challenge comparing with those obtained after the control bath.

\section{2. Second experiment - Injection challenges}

\section{2. 1. Animals studied}

199

200 The origin of the oysters used in this part of the study and the rearing procedures used are 201 described in detail by Normand et al. (2009). Briefly, diploid ( 2 n”) and triploid ( 3 nCB" and 2023 -3DT”) groups were produced in June 2006 by crosses between diploid genitors or between 203 diploid and tetraploid genitors. The 3nCB oysters were obtained by chemically-induced 204 retention of polar body II (Gérard et al., 1999) on diploid $\times$ diploid crosses, while 3nDT 205 oysters were obtained by crossing diploid females with tetraploid males (Guo et al., 1996). One diploid female, 16 diploid males and 16 tetraploid males were used to generate the corresponding progenies. This scheme of crosses allowed genetic differences between triploids and diploids to be minimized by using common genitors for the three groups as far as possible. Ploidy of these progenies was assessed by flow cytometry on two samples of 100 individuals per group, using DAPI staining of whole DNA content of the nucleus (Allen, 1983). Triploidy was thus confirmed to be over $95 \%$ successful for both $3 \mathrm{nCB}$ and $3 \mathrm{nDT}$ 212 groups.

213 All half-sib families were grown in the same zootechnical facilities and rearing site in order to 214 homogenize the environmental conditions among groups. Oyster rearing was conducted 215 following standard hatchery and nursery procedures, after which oysters were transferred to 216 plastic mesh bags, attached to off-bottom iron tables following the local farming practices in 217 the Bassin de Marennes Oléron (Charente-Maritime, France). All three groups were 218 monitored monthly throughout the rearing and experimental period. No significant mortality was ever observed in the oyster bags in the intertidal area during the period of challenge studies in the laboratory with animals of the same groups.

\section{2. 2. Experimental design of the injection challenges}

224 Three preliminary injection experiments were performed on sampled oysters from the three 225 groups during April 2007 in order to determine appropriate injection doses for a DL50. 
226 Four successive experimental challenges were performed starting on May $10^{\text {th }} 2007$ (date A), 227 June $26^{\text {th }} 2007$ (date B), August $29^{\text {th }} 2007$ (date C) and January $21^{\text {st }} 2008$ (date D), corresponding to different reproductive stages in the diploid oysters (Table 1). For each challenge, 42 to 69 (mean number $=57$ ) randomly sampled oysters from each group were placed in thermo-controlled aerated seawater in order to acclimate them to the seawater temperature at $20^{\circ} \mathrm{C}$ over five days before transfer to the infection room. Subsequently, 100 $\mu \mathrm{L}$ of a mix of virulent Vibrio suspension were injected into the adductor muscle of the oysters. The challenge procedures are described in Saulnier et al. (2010). In the present study, the two different virulent Vibrio strains belonging to both species frequently detected during oyster mortality outbreaks - Vibrio splendidus LGP32-GFP strain and Vibrio aestuarianus 02/041 strain (Garnier et al., 2007) - were used in equal concentration because of their synergistic effect (Saulnier et al., 2010). At each date, the pre-determined high dose and low dose were used, corresponding respectively to $10^{7}$ and $10^{6}$ total CFU injected per individual, as defined in the three preliminary injection experiments (see above). Negative controls consisted of a group of 20 to 36 oysters injected with sterile artificial seawater. At least three tanks were used per date, group and dose as experimental structure replicates (16 to 21 oysters per tank). Mortality was monitored twice a day and newly dead oysters were removed from each tank over a 6-day period. Moribund animals were checked for infection by LGP32-GFP and $02 / 041$ pathogenic strains using classical bacteriological analysis on haemolymph samples, and specific molecular-based-diagnostic tests (Saulnier et al., 2007).

\section{2. 3. Histological characterization}

Qualitative (reproductive stage, see Table 2) and quantitative (gonadic occupation, GO) monitoring of oyster reproductive effort was performed on subsamples of the experimental groups. A mean of 40 individual oysters were analysed per date and group. Histological slides of $C$. gigas tissues were analysed following the method described in Normand et al. (2009) to obtain the area fractions of gonadic tissue (GA) and the whole visceral mass area (WVMA).

254 Reproductive effort was estimated by gonadic occupation (GO) as: GO (\%) = GA x $100 /$ WVMA. Reproductive stage of diploid oysters was determined following a qualitative classification (5 stages from 0 to 4) adapted from Mann (1979) and Lango-Reynoso (2000). The reproductive stages of triploid oysters are not presented here due to the lack of an appropriate classification scale (Normand et al., 2009). 


\section{2. 4. Statistical analysis}

All statistical analyses were done with SAS (Statistical Analysis Software, V.9).

263 For each of the Vibrio injected oysters $(n=1245)$, we modelled the time from injection to 264 death. We eliminated those animals that had not died by the last assessment, 6 days post265 injection time from this analysis.

266 Considering the entire data set, we were first interested in modelling the effects of the 267 categorical predicators and their interactions on the survival functions. We built a general model including the following variables: experimental infection date (dates: A, B, C et D), experimental group (groups: 2n, 3nDT, 3nCB), treatment (injection doses: higher or lower) and experimental structure replicate (at least 3 replicates by date, group and dose). We used Cox proportional hazard model to perform regression analysis of survival data, employing the TPHREG procedure (Proportional Hazard Regression) that specifically allowed us to quantitatively examine the relationship between the survival kinetics of oysters, categorical variables and their interactions. We also used a contrast statement in order to test for effects of ploidy level (i.e. diploid versus triploid) and triploidy induction method (i.e. $3 \mathrm{nCB}$ versus 3nDT). The complete model first included all fixed effects and interaction terms between date, group, treatment and replicate. We then performed classical backward elimination procedure to obtain the final reduced model: Survival $=$ date + group + treatment + date $\times$ group + date $\times$ treatment.

280 This analysis detected highly significant interactions between infection date, group, and 281 treatment. We therefore performed univariate analysis using the non-parametric Kaplan-Meier method to test for differential performances among groups at the same date or within groups throughout the sampling period (Kaplan and Meier, 1958). We used the LIFETEST procedure to compute non-parametric estimates of the survival distribution function and generate mean survival time estimators. Equivalences between the survival curves within groups and among groups using the same infection dose were tested with Wilcoxon tests.

287 For the investigation of group and date effects on gonadic occupation, we verified the 288 homogeneity of variances using a Levene test (UNIVARIATE procedure) and values were squared-transformed to ensure homoscedasticity. An analysis of variance model (GLM procedure) (Littel et al., 2002) was finally built as: GOt $=$ date + group + date $\times$ group .

291 Due to a significant interaction between date and group, we tested for date effect within group 292 using a LS-means statement. We decided to exclude the values for gonadic occupation 
293 measured at date D, because gonadic occupation was null in all sampled individuals at this 294 time.

295

296 


\section{Results}

\section{1. Bath challenge and immunohistochemical analysis}

Mean survival at 13 days post-infection after $40 \mathrm{~h}$ bath challenge is presented in Fig. 1A. No significant mortality had occurred in control tanks and survival was very significantly lower in bath challenged tanks than in control tanks $\left(\chi^{2}=27.62, p<.0001\right)$. To our knowledge, this is the first time that experimental vibriosis infection using a bath protocol efficiently induced any mortality in C. gigas. A high variability of survival rates was found for bath challenge conditions, with one tank showing quite low mortality. Survival rates measured in the four tanks were $15 \%, 29 \%, 36 \%$ and $78 \%$. Furthermore, we found no significant differences in mortality with reproductive status $\left(\chi^{2}=1.18, p=0.5551\right.$; survival rates of $31 \%, 42 \%$ and 45 $\%$ for spawning, mature and non mature individuals, respectively).

Immunohistochemical analysis revealed that the mutant $V$. splendidus LGP32-GFP strain had infected different kinds of tissues in several oysters that died 7 days post-infection after $40 \mathrm{~h}$ of contact with this strain by bath challenge (Fig. 1B). In contrast, no labelling was observed in control animals, confirming the specificity of the diagnostic test. Numerous bacteria were detected for the first time in the gonadic tissue, but also in the adductor muscle, conjunctive tissue or digestive gland, with bacterial cells found alone or organized in foci (Fig. 1B, pictures $1,2,3,4,6,7$ and 8).

\section{2. The four injection challenges}

\section{2. 1. Reproductive status of oysters during the four injection experiments}

Histological analysis allowed us to determine the sexual maturation stages and gonadic occupation at the time of each experimental infection (Table 2) and to compare reproductive status of diploid and triploid oysters. 
331 At the time of the first infection (A), the majority of individuals in the diploid group had 332 initiated their reproductive maturation and presented early stages of gonadic development, with $7 \%$ of individuals in stage 1 and $90 \%$ in stage 2 (Fig. 2A); mean gonadic occupation was $34 \%$. Most triploid oysters (about $90 \%$ ) also presented immature gonadic tissues, with a lower - but significant - GO (16\%) compared with diploid individuals (Fig. 2B).

At the time of the second infection (B), all diploid oysters were ripe, i.e. in stage 3 , reaching complete maturation of their gonadic tissues and ready to spawn (Fig. 2A). Their mean GO was significantly higher than at the time of infection A $(68 \%)(p<0.0001)$. Triploid oysters presented a similar gonadic occupation as at infection A $(p=0.1302)$ (Fig. 2B). At the third infection (C), about $25 \%$ of diploid oysters were still in stage 3 while a larger proportion (about $50 \%$ ) were in the post-spawning stage (stage 4) (Fig. 2A). Moreover, the remaining quarter showed no development of gonadic tissues at all (stage 0), suggesting that they had spawned a few weeks before sampling (Fig. 2A). As a result, the mean GO of diploid oysters was lower than at the time of infection B $(49 \%)(\mathrm{p}<0.0001)$. A few triploid individuals still showed some gonadic maturation at date $\mathrm{C}$ with low mean $\mathrm{GO}$ (for $3 \mathrm{nDT}$ group, $\mathrm{p}<0.0001$ and for $3 \mathrm{nCB}$ group, $\mathrm{p}=0.0034)$, indicating that most oysters of the triploid groups underwent resorption of gonadic tissues.

348 Finally, as expected for the winter period, no sexual activity was observed at the time of infection D (100\% of individuals being in stage 0) (Fig. 2A).

350 Overall, clear reproductive differences were visible between diploid and triploid oysters at 351 infections $\mathrm{A}, \mathrm{B}$ and $\mathrm{C}$, while no difference was observed during the resting stage when 352 infection $\mathrm{D}$ was performed. The two types of triploid (3nCB and $3 \mathrm{nDT}$ ) showed similar 353 reproductive status over the sampling dates, except at infection $\mathrm{C}$ were $\mathrm{GO}$ was higher for $3 \mathrm{nDT}$ than for $3 \mathrm{nCB}$ ( $3 \%$ versus $11 \%$ respectively).

\section{2. 2. Injection dose characterization}

Two infection doses flanking the LD50 were determined in three preliminary experiments and used for the four injection experiments. The lower dose, corresponding to the injection of a mix of LGP32 and $02 / 041$ strains at $5 \times 10^{5} \mathrm{CFU}$ oyster $^{-1}$ for each strain, gave a mean survival rate of $76 \pm 15 \%$, whereas the higher dose, corresponding to the injection of a mix of LGP32 and $02 / 041$ strains at a dose of $5 \times 10^{6} \mathrm{CFU}$ oyster $^{-1}$ for each strain, gave a mean survival rate of $35 \pm 20 \%$. This dose determination allowed us to control the degree of severity of the challenge and to obtain analyzable variable survival rates. 
No mortality occurred in the control tanks in any of the experiments (data not shown). Mortality in the inoculated treatments was therefore considered to be due to the Vibrio mix. Moreover, molecular and classical bacteriological diagnostic tests confirmed the Vibrio infection with a high concentration, up to $10^{6} \mathrm{CFU} / \mathrm{ml}$, of the inoculated Vibrio found in individual haemolymph samples.

\section{2. 4. Survival of the injection challenge}

3. 2. 4. 1. The Proportional Hazard model with categorical covariates: multivariate approach

The contrast analysis done using the TPHREG procedure detected a significant differentiation between diploid and triploid groups $\left(\chi^{2}=6.12, p=0.013\right)$ but did not detect any effect of triploidy induction method $\left(\chi^{2}=0.22, \mathrm{p}=0.640\right)$ (Table 3$)$.

Global analysis revealed a very significant treatment effect $\left(\chi^{2}{ }_{1}=50.77, \mathrm{p}<.0001\right)$, which is due to the lower survival obtained with the higher injection dose. Date and group effects were also significant (respectively $\chi_{3}^{2}=10.24, \mathrm{p}=0.017 ; \chi^{2}{ }_{2}=6.17, \mathrm{p}=0.046$ ), as was their interaction $\left(\chi^{2}=11.44, \mathrm{p}=0.043\right)$ and the interaction between date and treatment $\left(\chi^{2}{ }_{3}=8.68\right.$, $\mathrm{p}=0.034)$. Consequently, we analysed survival functions with a univariate approach in order to further describe the variability of response to experimental vibriosis.

\section{2. 4. 2. Kaplan-Meier estimates of survival functions: univariate approach}

For each treatment, the survival distribution function, which represents the proportion of animals still alive each day of the period following injection, was characterized by the product-limit method (Kaplan and Meier, 1958), and plotted from the day of injection until the end of the test (Fig. 3).

The survival kinetics comparisons within groups and their mean survival times are presented in Fig. 3 and Figs 4A \& 4B, respectively.

397 For the lower dose and for $2 \mathrm{n}$ oysters, the mean survival time calculated at the date B was

398 substantially lower than at the other dates, even though the survival kinetics obtained were not 
statistically different between infection dates (date A: $5.3 \pm 0.2$ days, date B: $4.9 \pm 0.2$ days, date $C: 5.3 \pm 0.2$ days, date D: $5.3 \pm 0.1$ days) (Fig. 4A). At the higher dose, the mean survival time gradually rose from date $A$ to date $\mathrm{D}$, with increasing values from $3.4 \pm 0.2$ days (date A) to $4.1 \pm 0.1$ days (date D). For this dose, survival kinetics of diploid oysters obtained at date $\mathrm{D}$ were significantly different from those obtained at dates $\mathrm{A}(\mathrm{p}=0.0108)$ and $\mathrm{B}(\mathrm{p}=$ 0.0447) and similar to the one obtained at date $C$ (although $C$ was similar to those obtained at the dates A and B) (Fig. 4B).

In the same way, the survival kinetics obtained within 3nDT oysters were not statistically different from each other at the lower dose, with a minimum mean survival time at date A reaching $4.6 \pm 0.1$ days. The mean survival times calculated at dates $\mathrm{B}, \mathrm{C}$ and $\mathrm{D}$ were $5.2 \pm$ 0.2 days, $5.4 \pm 0.2$ days and $5.0 \pm 0.1$ days, respectively (Fig. 4A). At the higher dose, survival kinetics within $3 \mathrm{nDT}$ at the date $\mathrm{B}$ were significantly different to those observed at dates $C(p=0.0022)$ and $D(p=0.0022)$, which were similar to each other. The survival distribution function obtained at date $\mathrm{A}$ is similar to those obtained at dates $\mathrm{B}, \mathrm{C}$ and $\mathrm{D}$. The mean survival times calculated at dates $\mathrm{C}(3.7 \pm 0.2$ days $)$ and $\mathrm{D}(3.4 \pm 0.2$ days $)$ was higher than those calculated at dates A (2.9 \pm 0.2 days) and B (2.6 \pm 0.2 days) (Fig. 4B).

The same pattern of survival distribution functions was observed at both doses for the $3 \mathrm{nCB}$ group, and the kinetic obtained at date $\mathrm{C}$ for the higher dose was significantly different from those calculated at date $B(p<0.0001)$ and date $D(p=0.0002)$ (Figs 4A \& 4B). The maximum survival times for both doses were found at date $C$ (lower dose: $5.9 \pm 0.05$ days; higher dose: $4.6 \pm 0.2$ days). At date $\mathrm{B}$, survival reached $5.2 \pm 0.2$ days at the lower dose and $3.2 \pm 0.2$ days at the higher dose, while at date $\mathrm{D}$ it was $4.9 \pm 0.2$ days at the lower dose and $3.4 \pm 0.2$ days at the higher dose (Fig. 4B).

Comparisons of survival kinetics among groups and mean survival times are presented in Figs $3,4 \mathrm{~A} \& 4 \mathrm{~B}$.

The survival kinetics obtained for $2 \mathrm{n}$ and $3 \mathrm{nDT}$ groups at date A were statistically similar to each other for both doses (lower dose: $p=0.6119$; higher dose: $p=0.1298$ ). However, the mean survival time obtained for the $2 \mathrm{n}$ group $(5.3 \pm 0.2$ days at the lower dose and $3.4 \pm 0.2$ days at the higher dose) was higher than that obtained for the $3 \mathrm{nDT}$ group (4.6 \pm 0.1 days at the lower dose and $2.9 \pm 0.2$ days at the higher dose) (Figs 4A \& 4B).

At date $\mathrm{B}$, the $3 \mathrm{nDT}$ group presented a lower mean survival time than the $2 \mathrm{n}$ group at the higher dose $(p=0.053)(2 n: 3.5 \pm 0.2$ days, $3 n D T: 2.6 \pm 0.2$ days, $3 n C B: 3.2 \pm 0.2$ days $)$ 
432 whereas the other survival functions obtained for the three groups are alike for both doses 433 (Figs 4A \& 4B).

434 In experimental infection $\mathrm{C}$, the $3 \mathrm{nCB}$ group survival functions were significantly different 435 from those of the $2 \mathrm{n}$ (lower dose: $\mathrm{p}=0.0230$, higher dose: $\mathrm{p}=0.0325$ ) and $3 \mathrm{nDT}$ groups 436 (lower dose: $\mathrm{p}=0.0046$; higher dose: $\mathrm{p}=0.0023$ ). Mean survival times for the $3 \mathrm{nCB}$ group at 437 this date were $5.9 \pm 0.05$ days after the lower injection dose and $4.6 \pm 0.2$ days after the higher 438 injection dose (Figs 4A \& 4B). The survival functions obtained at both doses for the $2 \mathrm{n}$ group 439 (lower dose: $5.3 \pm 0.2$ days; higher dose: $3.9 \pm 0.2$ days) were similar to those obtained for the $4403 \mathrm{nDT}$ group (lower dose: $5.4 \pm 0.1$ days; higher dose: $3.7 \pm 0.2$ days).

441 At date $\mathrm{D}$, the $2 \mathrm{n}$ group survival function obtained at the higher dose was significantly 442 different from the triploid groups $(2 \mathrm{n} v s$. $3 \mathrm{nCB}$ group: $\mathrm{p}=0.0241 ; 2 \mathrm{n} v$ s. $3 \mathrm{nDT}$ group: $\mathrm{p}=$ $4430.0114)$, and the $2 \mathrm{n}$ mean survival time ( $4.1 \pm 0.2$ days) was higher than those of $3 \mathrm{nDT}(3.4 \pm$ 4440.2 days $)$ and $3 \mathrm{nCB}(3.4 \pm 0.2$ days $)$. At this date, the same order was obtained at the lower 445 dose, with $2 \mathrm{n}$ mean survival time at $5.3 \pm 0.2$ days, $3 \mathrm{nDT}$ at $5.0 \pm 0.2$ days and $3 \mathrm{nCB}$ at $4.9 \pm$ $446 \quad 0.2$ days (Figs 4A \& 4B).

447 


\section{Discussion}

\section{1. Potential and limitations of bath challenges versus injection}

Experimental infections of aquatic animals using viruses, bacteria or parasites can be performed to fulfil different objectives: to estimate the efficiency of preventive treatments, study routes of infection, test the resistance of selected lines (Gomez-Leon et al., 2008; Goyard et al., 2008; Lallias et al., 2008) or different ploidy groups (Ching et al., 2009; O'Flynn et al., 1997), and to assess host factors linked to susceptibility (Goarant et al., 1998; Goarant et al., 2006b; Labreuche et al., 2006a). For bacteria, experimental infections are also often used to explore pathogenicity (Gay et al., 2004; Goarant et al., 2006b), coupled with phenotypic and/or molecular characterization of virulence factors. Such experiments are used in epidemiological studies to assess the dynamics of infectious diseases (Goarant et al., 2006a; Guisande et al., 2008; Saulnier et al., 2000).

The best testing method may be co-habitation, bath or injection challenge, depending on objectives, analytical plan and biological characteristics of hosts and pathogens. In the case of $V$. splendidus or $V$. aestuarianus and Pacific oyster C. gigas, the bath method led to no vibriosis-induced mortality in groups of non sexually mature oysters (Labreuche et al., 2006a) and personal observations). As this type of protocol leads to significant mortality in other species (Farto et al., 2003; Kettunen and Fjalestad, 2006; Løvoll et al., 2009; Planas et al., 2005; Travers et al., 2008), the negative results obtained with C. gigas and Vibrio indicate the complex nature of infection processes in this model. However, the success of our bath experiment, carried out using sexually mature oysters led, for the first time, to significant mortality compared with controls, highlighting the importance of the stage of sexual maturity for Vibrio infection processes in oysters. However, our bath challenge protocol showed poor repeatability between tanks. It appeared that this method did not create a common challenge to all animals, probably due to the multiplicity of events which could have occurred between the time the water was contaminated and the moment when the Vibrio entered the oyster. Moreover, we cannot exclude the possibility that the artificial reproduction conditioning might have had an effect on immune-physiological status and susceptibility to vibriosis of tested oysters. Nonetheless, this bath protocol could be used to map the route of Vibrio

482 infection on both spatial and temporal scales. The observed success of our bath protocol in 
presence of mature and spawning animals led us to focus on the links between reproduction 484 and survival to vibriosis on related diploid and triploid oysters at different stages of their reproductive cycle, using a standardized injection protocol.

Considering the implication of Vibrio splendidus and V. aestuarianus in mortality events of the Pacific oyster C. gigas, a reproducible experimental co-infection model was recently developed in order to provide an integrative tool for the better understanding of summer mortality (Saulnier et al., 2010). In the present study, experimental infections were carried out paying particular attention to the reproducibility of all controllable parameters: preparation of the inocula, injection procedures, density, seawater quality, tanks, temperature, aeration, mortality survey specification. We ensured that all animals were at equal risk of being infected by using the same amount of bacterial inoculum at the four different dates over the year. Moreover, the fact that no mortality was observed in control tanks during any of the injection experiments strongly suggests that the mortality in Vibrio challenge tanks was due to the injected Vibrio mix. Furthermore, we verified with the plate-counting method and molecular diagnostic tests that haemolymph samples from some freshly dead oysters harboured dominant bacteria belonging to the same species as those injected (data not shown), fulfilling one of the Koch's postulates and confirming the Vibrio infection was the cause of death. Besides these verifications, the clear dose effect, observed at each date, confirmed Vibrio infection. In the light of these results, we can be confident that experimental injections were performed under as uniform conditions as possible, allowing an objective comparison of the four sampling dates.

Nevertheless, although survival of control oysters injected with sterile artificial seawater was not affected (i.e. $100 \%$ survival rates observed at each condition), it is obvious that this procedure of experimental infection is invasive and bypasses the natural means of entrance of virulent Vibrio into the host tissues and, in this way, bypasses the first lines of defence. However, even though this injection procedure does not mimic the natural route of infection, it allowed experimental co-infection to be tested in a way that led to repeatable vibriosis mortality results. This allowed us to further investigate to importance of reproductive status, modulated by ploidy and time, on resistance to vibriosis.

515 Lastly, summer mortality under natural conditions arises from a complex interaction of 516 factors (Samain and McCombie, 2008) that we cannot claim to have reproduced under 
experimental conditions. We worked under controlled experimental conditions to assess the

518 effect of sexual maturity and ploidy, both of which appear to be relevant. It should also be noted also that we cannot totally exclude the implication of other factors that covaried over time with the reproductive status of the studied oysters.

\section{2. Statistical analysis of survival kinetics}

The final general Cox model using TPHREG procedures (Cox, 1972) allowed us to quantitatively examine the overall relationship between susceptibility of challenged oysters and several chosen factors. The power and originality of this procedure lies in its use of categorical variables and interactions. It computes statistical tests using realistic degrees of freedom and is therefore the procedure best suited to our data, although it is still in the testing phase. Similar results were obtained using the more classical PHREG procedure (data not shown). This type of analysis has rarely been used on aquatic animals, although it is widely applied in medical statistics as it provides the hazard ratio - or the risk of death - assessment, according to treatment and prognostic variables (Arriagada et al., 2009; Kwok et al., 2010). These analyses confirmed the value of this kind of experimental challenge tool, indicating that it could be adapted and integrated into multidisciplinary studies on shellfish mortality events and used to identify host factors and interactions that influence bacterial virulence and aggravate infectious disease.

537 In further studies, growth could be monitored to improve the interpretation of variability of 538 survival, although no clear differences in growth pattern were detected between groups. Similar trends were observed regarding summer mortality of oysters in the field (Dégremont et al., 2005). The inclusion of individual quantitative phenotypic data describing sexual maturation or somatic growth in the general model would allow the relationship between survival and reproductive effort to be assessed at an individual scale. Such data is not easy to obtain, as non-destructive methods to quantify reproductive status of oysters are still in development (Davenel et al., 2006). 
551 As already mentioned, the present study, examining the reaction of sexually mature oysters to 552 bath challenge, revealed significant mortality. Even though the Vibrio entry route remains to 553 be identified, numerous $V$. splendidus-GFP bacteria were specifically detected in gonadic 554 tissues, using the specific immunohistochemical method (Fig. 1B). The organisation in foci 555 reinforces the hypothesis that Vibrio has an affinity for this kind of tissue. Gonadic tissue 556 could constitute both a facilitated route of entrance and a highly nutritive tissue, favourable to 557 Vibrio infection and establishment. Following this hypothesis, Vibrio infection could be 558 considerably amplified by high gonadic tissue weight, which can account for up to $86 \%$ of 559 the individual body weight at maturity (Deslous-Paoli and Héral, 1988; Enríquez-Díaz et al., 560 2009). Even though mortality rates were variable among tanks, this new result underlines the 561 involvement of sexual maturity in oyster susceptibility to vibriosis; more precisely the 562 transmissibility of Vibrio within oysters through gonadic tissue or between oysters via 563 spawning. Nevertheless, considering the complexity of infection processes, we cannot use 564 such an approach to define the precise mechanism that compromises the immune responses of 565 C. gigas. However, it is interesting to note that extracellular proteases, e.g. metalloproteases, 566 could facilitate the invasion process in gonadic tissue due to their proteolytic activity. 567 Metalloproteases are (1.) known to be involved in tissue invasion and the modulation and/or 568 destruction of host defence (Travis et al., 1995); (2.) described in both of the studied strains of $569 V$. splendidus and $V$. aestuarianus pathogenic to $C$. gigas, as essential determinants of 570 virulence (Binesse et al., 2008; Labreuche et al., 2006b); and (3.) are a common feature of 571 pathogenic bacteria strains associated with mortality events in C. gigas reared in France 572 (Saulnier et al., 2010). The affinity of the bacteria for gonadic tissues underlined in the 573 present study should probably be considered as an aggravating factor that acts in synergy with 574 energetic re-allocation from survival to reproduction to increase oyster vulnerability to 575 vibriosis.

576 The significant variations in resistance to experimental infections over the reproductive cycle 577 could be linked to sexual maturation. One major trend is the increase of survival at date C 578 compared with dates $\mathrm{A}$ and $\mathrm{B}$, observed for all the three groups and both treatments. 579 Considering the trade-off between reproduction and survival in C. gigas, it is tempting to correlate this date effect with reproductive status and interpret this variation of susceptibility 581 as an effect of the sexual maturation on survival performances. Diploid individuals are indeed 582 known to make a high energetic allocation to reproductive tissues, (estimated at $55 \%$ of the 583 annual energy budget) (Van der Meer, 2006). Such a reproductive effort could result in 584 physiological weakness that prevents oysters from responding efficiently to vibriosis 
infection; this has been widely evoked as a part of the explanation for summer mortality of cultured oysters in France (Delaporte et al., 2006; Duchemin et al., 2007; Gagnaire et al., 2006; Li et al., 2009a; Pouvreau and Lepennec, 2006; Soletchnik et al., 1997). Interestingly, lower phagocytic activity and adhesive capacity of oyster haemocytes were reported during the reproductive season (Delaporte et al., 2006; Gagnaire et al., 2006; Li et al., 2009b). Furthermore, energy balance probably did not explain all costs at the mature stage. The very high gonad development in C. gigas may result in mechanical difficulties, as gonad size and density probably affect haemolymph circulation (Tran et al., 2008). We suspect that the observed decrease in resistance to experimental infection during the period of active gonadogenesis is due to both the energetic and mechanic disturbance caused by gonad formation.

This interpretation is mainly based on the observed covariation between mean group GO and survival at any given time, although alternative experimental approaches could be used to test for a causal relationship between gonad development dynamics and increasing susceptibility to summer mortality. The production of divergent lines for reproductive allocation (Normand, 2009) or resistance to summer mortalities (Dégremont et al., 2007) could also constitute interesting material to further investigate this point, especially as a genetic correlation has been observed between these two traits (Ernande et al., 2004; Huvet et al., 2010).

\section{3. 2. Triploid responses to experimental vibriosis: indications of sexual maturation costs}

Considering the whole sampling period and both triploid groups, we did not observe higher survival in triploid individuals than in diploid ones. This result leads to the conclusion that the reduction of gonadic development in triploid oysters does not lead to a significant improvement of resistance to experimental vibriosis. Under natural conditions, previous studies reported variable results on the relative resistance of diploid and triploid oysters to summer mortality (Allen and Downing, 1986; Cheney et al., 2000; Gagnaire et al., 2006; Garnier-Géré et al., 2002). As triploid oysters often show better growth than diploids (Allen and Downing, 1986; Nell and Perkins, 2005), this is commonly presumed to be mainly related to energy reallocation from gonadic development to somatic growth.

In our second experiment, at date $\mathrm{C}$, both types of triploid oysters showed a similar higher resistance to experimental vibriosis compared with diploids. This result was not repeated on the other dates, suggesting that triploid oysters might have reduced resistance during the 
619 reproductive period, possibly due to some sort of reproductive cost. This hypothesis is supported by the fact that histological analysis revealed a significant development of gonadic 621 tissue in both triploid groups, indicating a significant allocation to reproduction in these individuals, as reported in some previous studies (Allen and Downing, 1990; Normand et al., 2009). Additionally, it is probable that the measurements of gonadic occupation did not fully reflect the amount of energy devoted to reproduction in triploid oysters, notably because they have the tendency to resorb reproductive tissue before reaching full maturity (Allen and Downing, 1990; Normand et al., 2008; Shpigel et al., 1992). Clearly, such spontaneous atresia tends to disconnect the measured GO at a given time from the true allocation to reproduction, which would be underestimated in this case.

Moreover, histological observations of atresic tissues in diploid and triploid oysters typically showed massive haemocyte infiltrations, which could be interpreted as an inflammatory phenomenon that could also lead to excess costs, independent of energetic allocation to reproduction (Delaporte et al., 2007). Knowing that such reproductive tissue degeneration processes are far more common in triploid than in diploid oysters (Allen and Downing, 1990; Shpigel et al., 1992), the disturbed reproductive tissue development in triploid oysters might result in some additional underestimated costs. It appears difficult in this context to precisely estimate the energetic allocation to reproduction in triploid individuals, a practical problem that was already pointed out in a previous study (Normand et al., 2009). Our experimental approach of estimating allocation to reproduction by direct measure of gonad development and maturity and measuring the costs paid by physiological covariates like survival goes some way to offering a solution to this problem.

\section{3. 3. Evidence for winter depression in triploid oysters}

Ultimately, the two triploid groups appeared more susceptible to experimental vibriosis infection at date $\mathrm{D}$ (resting period) than at date $\mathrm{C}$, while this was not the case for the diploid oysters, which showed a gradual increase in survival during the autumn and winter period. This suggests an intrinsic weakness of triploid oysters at a time when diploid survival remains unaffected by the costs of reproductive activity. Following this hypothesis, another physiological function could be acting as an energetic sink in triploid oysters, meaning that these individuals require more resources to survive. Such a hypothesis, of an extra maintenance cost in triploid oysters during the winter season, could also explain the recurrent 
653

654

655

656

657

658

659

660

661

662

663

664

665

666

667

668

669

670

671

672

673

674

675

676

677

678

679

680

681

682

683

684

685

686

reports of high autumnal weight loss in these individuals or unexpected consumption of carbohydrate reserves (Allen and Downing, 1986; Lambert et al., 2008). In fact, some evidence already suggests that induced triploidy could lead to general detrimental effects on growth and survival. In fish, triploid individuals are generally surpassed by their diploid counterparts until they gain an advantage from their reduced reproductive development (Piferrer et al., 2009). Growth and survival is slightly depressed in triploid salmonids, but they usually overtake diploid individuals when the latter reach sexual maturity (Chourrout et al., 1986; Quillet et al., 1988). Experimental Vibrio challenges conducted on diploid and triploid Chinook salmon also illustrate reduced performance of triploid individuals (Ching et al., 2009).

However, previous studies have proposed that improved growth in triploid molluscs could be explained by an increase in net energy budget (Hawkins et al., 2000; Hawkins et al., 1994; Wang et al., 2002), a phenomenon independent of energetic re-allocation from reproduction to other functions. Such results have been thought to be due to increased heterozygosity in polyploid individuals, suggesting that triploidy could confer an advantage per se on growth and survival through the increase of intra-individual allelic diversity and the optimisation of energy balance (Hawkins et al., 2000). Other studies found conflicting results, with very few differences in energy budget detected between diploid and triploid Sydney rock oysters (Kesarcodi-Watson et al., 2001a; Kesarcodi-Watson et al., 2001b) or clams (Mason et al., 1988). These authors explained the observed difference in growth rates as the result of reallocation from reproduction. At present, the hypothesis of a per se triploid survival advantage appears doubtful in molluscs.

\section{Conclusion}

To summarize, we propose a scenario linking our experimental observations with the summer mortality episodes observed under natural environmental conditions. Working at different dates over a year on oysters issued from one controllable experimental production and reared under common environmental condition allowed us to better document the effect of reproduction on oyster resistance to Vibrio challenge. During the period of active sexual maturation, survival performances in oysters challenged with experimental vibriosis were lower than those recorded after spawning. This suggests that the individual resistance to a pathogenic threat varies through the year as a result of a physiological trade-off between 
687

688

689

690

691

692

693

694

695

696

697

698

699

700

701

702

703

704

705

706

707

708

709

710

711

712

713

714

reproduction and survival. We suspect that such a trade-off is primarily made up of energetic components, but is also influenced by additional components that are independent of energetic allocation. Previously published studies have already pointed out the fact that this summer period of physiological weakness probably coincides with a period when exogenous stresses (temperature, pollutants) (Samain and McCombie, 2008) and pathogenic pressures (Thompson et al., 2006) are exacerbated. The conjunction of increased susceptibility of the host and environmental and pathogenic stressors results in the mass mortalities observed in reared stocks of C. gigas.

We found that despite their reduced reproductive tissue development, triploid individuals did not show better performances than diploid ones when considering the entire period of the study. This could be due to underestimated costs of reproductive activity for triploid oysters. Reduced triploid survival performances in winter also suggest an intrinsic depression in triploid performance compared with diploids, potentially compensated during the reproductive period. In this case, although winter would correspond to a period of physiological weakness in triploid oysters, this probably does not lead to such heavy mortality as that observed in summer because the pathogen pressure is lower.

\section{Acknowledgements}

We are grateful to the hatchery teams at the La Tremblade and Bouin Ifremer stations for their help with the production of the oysters used in the present study. We thank Dr. Frédérique Le Roux (Harvard Medical School, formerly at Institut Pasteur) for providing the Vibrio splendidus LGP32 mutated strain expressing a resistance to chloramphenicol antibiotic and a Green Fluorescent Protein. Thanks also to Patrick Soletchnik and Nicolas Taris for their analytical contribution and to Philippe Haffner and Emmanuelle Omnes for their technical help. We are particularly grateful to Ismaël Bernard for his help and support on theoretical ecophysiology background, Ronan Becheler for writing suggestions, Yann Reynaud for critical reading of the manuscript and Helen McCombie for help with the English. 


\section{References}

Allen, S. K., 1983. Flow cytometry: assaying experimental polyploidy fish and shellfish. Aquaculture. 33, 317-328.

Allen, S. K., Downing, S. L., 1986. Performance of triploid Pacific oysters, Crassostrea gigas (Thunberg). I. Survival, growth, glycogen content, and sexual maturation in yearlings. J. Exp. Mar. Biol. Ecol. 102, 197-208.

Allen, S. K., Downing, S. L., 1990. Performance of triploid Pacific oysters, Crassostrea gigas: Gametogenesis. Can. J. Fish. Aquat. Sci. 47, 1213-1222.

Arriagada, R., Dunant, A., Pignon, J.-P., Bergman, B., Chabowski, M., Grunenwald, D., Kozlowski, M., Le Pechoux, C., Pirker, R., Pinel, M.-I. S., Tarayre, M., Le Chevalier, T., 2009. Long-Term Results of the International Adjuvant Lung Cancer Trial Evaluating Adjuvant Cisplatin-Based Chemotherapy in Resected Lung Cancer. J. Clin. Oncol. 28, 35-42.

Beattie, J. H., Chew, K. K., Hershberger, W. K., 1980. Differential survival of selected strains of Pacific oysters (Crassostrea gigas) during summer mortality. Proc. Natl. Shellfish Assoc. 70, 184-189.

Binesse, J., Delsert, C., Saulnier, D., Champomier-Verges, M. C., Zagorec, M., Munier-

Boudry, P., Dégremont, L., Haffray, P., The genetic basis of summer mortality in Pacific oyster and potential for improving survival by selective breeding in France. In: J. F. Samain, H. McCombie, (Eds.), Summer mortality of Pacific oyster Crassostrea gigas. The Morest Project, Editions Ifremer/Quae, Paris, 2008, pp. 153-196.

Cheney, D. P., MacDonald, B. F., Elston, R. A., 2000. Summer mortality of Pacific oysters, Puget Sound, Washington, 1998. J. Shellfish Res. 19, 353-359. 
Ching, B., Jamieson, S., Heath, J. W., Heath, D. D., Hubberstey, A., 2009. Transcriptional differences between triploid and diploid Chinook salmon (Oncorhynchus tshawytscha) during live Vibrio anguillarum challenge. Heredity. 104, 224.

Chourrout, D., Chevassus, B., Krieg, F., Happe, A., Burger, G., Renard, P., 1986. Production of second generation triploid and tetraploid rainbow trout by mating tetraploid males and diploid females - Potential of tetraploid fish. Theor. Appl. Genet. 72, 193-206.

Cox, D. R., 1972. Regression Models and Life-Tables. J. R. Stat. Soc. 34, 187-220.

Davenel, A., Quellec, S., Pouvreau, S., 2006. Noninvasive characterization of gonad maturation and determination of the sex of Pacific oysters by MRI. Magn. Reson. Imaging. 24, 1103.

Dégremont, L., Bédier, E., Soletchnik, P., Ropert, M., Huvet, A., Moal, J., Samain, J.-F., Boudry, P., 2005. Relative importance of family, site, and field placement timing on survival, growth, and yield of hatchery-produced Pacific oyster spat (Crassostrea gigas). Aquaculture. 249, 213-229.

Dégremont, L., Ernande, B., Bédier, E., Boudry, P., 2007. Summer mortality of hatcheryproduced Pacific oyster spat (Crassostrea gigas). I. Estimation of genetic parameters for survival and growth. Aquaculture. 262, 41-53.

Delaporte, M., Soudant, P., Lambert, C., Jegaden, M., Moal, J., Pouvreau, S., Dégremont, L., Boudry, P., Samain, J.-F., 2007. Characterisation of physiological and immunological differences between Pacific oysters (Crassostrea gigas) genetically selected for high or low survival to summer mortalities and fed different rations under controlled conditions. J. Exp. Mar. Biol. Ecol. 353, 45-57.

Delaporte, M., Soudant, P., Lambert, C., Moal, J., Pouvreau, S., Samain, J.-F., 2006. Impact of food availability on energy storage and defense related hemocyte parameters of the Pacific oyster Crassostrea gigas during an experimental reproductive cycle. Aquaculture. 254, 571-582.

Deslous-Paoli, J.-M., Héral, M., 1988. Biochemical composition and energy value of Crassostrea gigas (Thunberg) cultured in the bay of Marennes-Oléron. Aquat. Living Resour. 1, 239-249.

Duchemin, M. B., Fournier, M., Auffret, M., 2007. Seasonal variations of immune parameters in diploid and triploid Pacific oysters, Crassostrea gigas (Thunberg). Aquaculture. 264, 73-81.

Enríquez-Díaz, M., Pouvreau, S., Chávez-Villalba, J., Le Pennec, M., 2009. Gametogenesis, reproductive investment, and spawning behavior of the Pacific giant oyster 
Crassostrea gigas: evidence of an environment-dependent strategy. Aquacult. Int. 17, 491.

Ernande, B., Boudry, P., Clobert, J., Haure, J., 2004. Plasticity in resource allocation based life history traits in the Pacific oyster, Crassostrea gigas. I. Spatial variation in food abundance. J. Evol. Biol. 17, 342-356.

Fabioux, C., Huvet, A., Le Souchu, P., Le Pennec, M., Pouvreau, S., 2005. Temperature and photoperiod drive Crassostrea gigas reproductive internal clock. Aquaculture. 250, 458-470.

Farto, R., Armada, S. P., Montes, M., Guisande, J. A., Pérez, M. J., Nieto, T. P., 2003. Vibrio lentus associated with diseased wild octopus (Octopus vulgaris). J. Invertebr. Pathol. 83, 149-156.

Gagnaire, B., Soletchnik, P., Madec, P., Geairon, P., Le Moine, O., Renault, T., 2006. Diploid and triploid Pacific oysters, Crassostrea gigas (Thunberg), reared at two heights above sediment in Marennes-Oleron Basin, France: Difference in mortality, sexual maturation and hemocyte parameters. Aquaculture. 254, 606-616.

Garnier-Géré, P. H., Naciri-Graven, Y., Bougrier, S., Magoulas, A., Héral, M., Kotoulas, G., Hawkins, A., Gérard, A., 2002. Influences of triploidy, parentage and genetic diversity on growth of the Pacific oyster Crassostrea gigas reared in contrasting natural environments. Mol. Ecol. 11, 1499-1514.

Garnier, M., Labreuche, Y., Garcia, C., Robert, M., Nicolas, J. L., 2007. Evidence for the involvement of pathogenic bacteria in summer mortalities of the Pacific oyster Crassostrea gigas. Microb. Ecol. 53, 187-196.

Gay, M., Berthe, F. C., Le Roux, F., 2004. Screening of Vibrio isolates to develop an experimental infection model in the Pacific oyster Crassostrea gigas. Dis. Aquat. Org. $59,49-56$.

Gérard, A., Ledu, C., Phélipot, P., Naciri-Graven, Y., 1999. The induction of MI and MII triploids in the Pacific oyster Crassostrea gigas with 6-DMAP or CB. Aquaculture. $174,229-242$.

Goarant, C., Ansquer, D., Herlin, J., Domalain, D., Imbert, F., De Decker, S., 2006a. "Summer Syndrome" in Litopenaeus stylirostris in New Caledonia: Pathology and epidemiology of the etiological agent, Vibrio nigripulchritudo. Aquaculture. 253, 105113. 
813 Goarant, C., Régnier, F., Brizard, R., Marteau, A.-L., 1998. Acquisition of susceptibility to Vibrio penaeicida in Penaeus stylirostris postlarvae and juveniles. Aquaculture. 169, 291-296.

816 Goarant, C., Reynaud, Y., Ansquer, D., De Decker, S., Saulnier, D., Roux, F. 1., 2006 b. Molecular epidemiology of Vibrio nigripulchritudo, a pathogen of cultured penaeid shrimp (Litopenaeus stylirostris) in New Caledonia. Syst. Appl. Microbiol. 29, 570580.

Gomez-Leon, J., Villamil, L., Salger, S. A., Sallum, R. H., Remacha-Trivino, A., Leavitt, D. F., Gomez-Chiarri, M., 2008. Survival of eastern oysters Crassostrea virginica from three lines following experimental challenge with bacterial pathogens. Dis. Aquat. Org. 79, 95-105.

Goyard, E., Goarant, C., Ansquer, D., Brun, P., de Decker, S., Dufour, R., Galinié, C., Peignon, J.-M., Pham, D., Vourey, E., Harache, Y., Patrois, J., 2008. Cross breeding of different domesticated lines as a simple way for genetic improvement in small aquaculture industries: Heterosis and inbreeding effects on growth and survival rates of the Pacific blue shrimp Penaeus (Litopenaeus) stylirostris. Aquaculture. 278, 4350.

Guisande, J. A., Perez Lago, E., Prado, S., Nieto, T. P., Farto Seguin, R., 2008. Genotypic diversity of culturable Vibrio species associated with the culture of oysters and clams in Galicia and screening of their pathogenic potential. J. Shellfish Res. 27, 801-809.

Guo, X., DeBrosse, G. A., Allen, S. K., 1996. All-triploid Pacific oysters (Crassostrea gigas 835 Thunberg) produced by mating tetraploids and diploids. Aquaculture. 142, 149-161.

Hawkins, A., Magoulas, A., Héral, M., Bougrier, S., Naciri-Graven, Y., Day, A. J., Kotoulas, behaviour, metabolic efficiency and net energy balance in the Pacific oyster Crassostrea gigas. Genet. Res. 76, 273-284.

Hawkins, A. J. S., Day, A. J., Gérard, A., Naciri, Y., Ledu, C., Bayne, B. L., Héral, M., 1994. A genetic and metabolic basis for faster growth among triploids induced by blocking meiosis I but not meiosis II in the larviparous European flat oyster, Ostrea edulis L. J. Exp. Mar. Biol. Ecol. 184, 21-40.

Huvet, A., Normand, J., Fleury, E., Quillien, V., Fabioux, C., Boudry, P., 2010. Reproductive effort of Pacific oysters: A trait associated with susceptibility to summer mortality. Aquaculture. 304, 95-99. 
Kaplan, E. L., Meier, P., 1958. Nonparametric estimation from incomplete observations. J. Am. Stat. Assoc. 53, 457-481.

Kesarcodi-Watson, A., Klumpp, D. W., Lucas, J. S., 2001a. Comparative feeding and physiological energetics in diploid and triploid Sydney rock oysters (Saccostrea commercialis): II. Influences of food concentration and tissue energy distribution. Aquaculture. 203, 195.

Kesarcodi-Watson, A., Lucas, J. S., Klumpp, D. W., 2001b. Comparative feeding and physiological energetics of diploid and triploid Sydney rock oysters, Saccostrea commercialis: I. Effects of oyster size. Aquaculture. 203, 177.

Kettunen, A., Fjalestad, K. T., 2006. Resistance to vibriosis in Atlantic cod (Gadus morhua L.): First challenge test results. Aquaculture. 258, 263-269.

Kooijman, S. A. L. M., 2000. Dynamic energy and mass budgets in biological systems. Cambridge University Press, Cambridge, UK.

Kwok, J., Langevin, S. M., Argiris, A., Grandis, J. R., Gooding, W. E., Taioli, E., 2010. The impact of health insurance status on the survival of patients with head and neck cancer. Cancer. 116, 476-485.

Labreuche, Y., Lambert, C., Soudant, P., Boulo, V., Huvet, A., Nicolas, J. L., 2006a. Cellular and molecular hemocyte responses of the Pacific oyster, Crassostrea gigas, following bacterial infection with Vibrio aestuarianus strain 01/32. Microbes Infect. 8, 2715-24.

Labreuche, Y., Soudant, P., Goncalves, M., Lambert, C., Nicolas, J. L., 2006b. Effects of extracellular products from the pathogenic Vibrio aestuarianus strain 01/32 on lethality and cellular immune responses of the oyster Crassostrea gigas. Dev. Comp. Immunol. 30, 367-79.

Lacoste, A., Jalabert, F., Malham, S., Cueff, A., Gelebart, F., Cordevant, C., Lange, M., Poulet, S. A., 2001. A Vibrio splendidus strain is associated with summer mortality of juvenile oysters Crassostrea gigas in the Bay of Morlaix (North Brittany, France). Dis. Aquat. Org. 46, 139-45.

Lallias, D., Arzul, I., Heurtebise, S., Ferrand, S., Chollet, B., Robert, M., Beaumont, A. R., Boudry, P., Morga, B., Lapègue, S., 2008. Bonamia ostreae-induced mortalities in one-year old European flat oysters Ostrea edulis: experimental infection by cohabitation challenge. Aquat. Living Resour. 21, 423-439.

Lambert, C., Moal, J., Le Moullac, G., Pouvreau, S., Les risques associés à la physiologie de l'huître en période de reproduction. In: J. Samain, H. McCombie, (Eds.), Mortalités 
estivales de l'huître creuse Crassostrea gigas. Défi Morest, Ifremer/Quae, Paris, 2008, pp. 153-196.

Lango-Reynoso, F., Chávez-Villalba, J., Cochard, J. C., Le Pennec, M., 2000. Oocyte size, a means to evaluate the gametogenic development of the Pacific oyster, Crassostrea gigas (Thunberg). Aquaculture. 190, 183-199.

Le Roux, F., Gay, M., Lambert, C., Waechter, M., Poubalanne, S., Chollet, B., Nicolas, J. L., Berthe, F., 2002. Comparative analysis of Vibrio splendidus-related strains isolated during Crassostrea gigas mortality events. Aquat. Living Resour. 15, 251-258.

Li, Y., Qin, J. G., Li, X., Benkendorff, K., 2009a. Monthly variation of condition index, energy reserves and antibacterial activity in Pacific oysters, Crassostrea gigas, in Stansbury (South Australia). Aquaculture. 286, 64-71.

Li, Y., Qin, J. G., Li, X., Benkendorff, K., 2009b. Spawning-dependent stress response to food deprivation in Pacific oyster Crassostrea gigas. Aquaculture. 286, 309-317.

Littel, R., Stroup, W., Freund, J., 2002. SAS for Linear Models, Fourth Edition., Cary, NC, USA.

Løvoll, M., Wiik-Nielsen, C. R., Tunsjø, H. S., Colquhoun, D., Lunder, T., Sørum, H., Grove, S., 2009. Atlantic salmon bath challenged with Moritella viscosa - Pathogen invasion and host response. Fish Shellfish Immunol. 26, 877-884.

Mann, R., 1979. Some biochemical and physiological aspects of growth and gametogenesis in Crassostrea gigas and Ostrea edulis grown at sustained elevated temperature. J. Mar. Biol. Assoc. U.K. 59, 95-110.

Mason, K. M., Shumway, S. E., Allen, S. K. J., Hidu, H., 1988. Induced triploidy in the softshelled clam Mya arenaria: energetic implications. Mar. Biol. 98, 519-582.

Mori, K., 1979. Effects of artificial eutrophication on the metabolism of the Japanese oyster Crassostrea gigas. Mar. Biol. 53, 361-369.

Nell, J. A., Perkins, B., 2005. Studies on triploid oysters in Australia: farming potential of alltriploid Pacific oysters, Crassostrea gigas (Thunberg), in Port Stephens, New South Wales, Australia. Aquac. Res. 36, 530-536.

Normand, J., Déterminismes génétiques de l'allocation à la reproduction chez les huîtres creuses (Crassostrea gigas) triploïdes. Laboratoire de Génétique et Pathologie, IFREMER. Université de La Rochelle, France, 2009, pp. 224.

Normand, J., Ernande, B., Haure, J., McCombie, H., Boudry, P., 2009. Reproductive effort and growth in Crassostrea gigas: comparison of young diploid and triploid oysters issued from natural crosses or chemical induction. Aquat. Biol. 7, 229-241. 
Normand, J., Le Pennec, M., Boudry, P., 2008. Comparative histological study of gametogenesis in diploid and triploid Pacific oysters (Crassostrea gigas) reared in an estuarine farming site in France during the 2003 heatwave. Aquaculture. 282, 124129.

O'Flynn, F. M., McGeachy, S. A., Friars, G. W., Benfey, T. J., Bailey, J. K., 1997. Comparisons of cultured triploid and diploid Atlantic salmon (Salmo salar L.). ICES J. Mar. Sci. 54, 1160-1165.

Perdue, J. A., Beattie, J. H., Kenneth, K. C., 1981. Some relationships between gametogenetic cycle and summer mortality phenomenon in the Pacific oyster (Crassostrea gigas) in Washington State. J. Shellfish Res. 1, 9-16.

Piferrer, F., Beaumont, A., Falguière, J.-C., Flajshans, M., Haffray, P., Colombo, L., 2009. Polyploid fish and shellfish: Production, biology and applications to aquaculture for performance improvement and genetic containment. Aquaculture. 293, 125-156.

Planas, M., Perez-Lorenzo, M., Antonio Vazquez, J., Pintado, J., 2005. A model for experimental infections with Vibrio (Listonella) anguillarum in first feeding turbot (Scophthalmus maximus L.) larvae under hatchery conditions. Aquaculture. 250, 232243.

Pouvreau, S., Enriquez-Diaz, M., Le Souchu, P., Connan, J. P., Le Roy, B., Mingant, C., Moal, J., Delaporte, M., Le Coz, J. R., Samain, J. F., Reproduction, bioenergetic and summer mortality of Crassostrea gigas: experimental approach. In: N. S. Association, (Ed.), Annual Meeting of The National Shellfisheries Association, Vol. 22, NewOrleans, LA (USA), 2003, pp. 351.

Pouvreau, S., Lepennec, M., 2006. Ecophysiology of the reproduction of cupped oyster, Crassostrea gigas. IFREMER.

Quillet, E., Chevassus, B., Blanc, J., Krieg, F., Chourrout, D., 1988. Performances of auto and allotriploids in salmonids. I. Survival and growth in fresh water farming. Aquat. Living Resour. 1, 29-43.

Renault, T., Le Deuff, R., Cochennec, N., Chollet, B., Maffart, P., 1995. Herpes-like viruses associated with high mortality levels in larvae and spat of Pacific oysters, Crassostrea gigas: A comparative study, the thermal effects on virus detection in hatchery-reared larvae, reproduction of the disease in axenic larvae. Vet. Res. 26, 539-543.

Samain, J. F., McCombie, H., 2008. Summer mortality of Pacific oyster Crassostrea gigas. The Morest Project. 379p. 
Saulnier, D., De Decker, S., Haffner, P., 2009. Real-time PCR assay for rapid detection and quantification of Vibrio aestuarianus in oyster and seawater: A useful tool for epidemiologic studies. J. Microbiol. Methods. 77, 191-197.

Saulnier, D., De Decker, S., Haffner, P., Cobret, L., Robert, M., Garcia, C., 2010. A largescale epidemiological study to identify bacteria pathogenic to Pacific oyster Crassostrea gigas and correlation between virulence and metalloprotease-like activity. Microb. Ecol. 59, 787-798.

Saulnier, D., De Decker, S., Haffner, P., Duperthuy, M., Le Roux, F., Development of diagnostic tools for the detection of Vibrio species and pathogenic strains associated with mortalities of cultured pacific cupped oyster Crassostrea gigas in France. Vibrio 2007 meeting, Pasteur Institute, Paris (France), 2007, pp. 191.

Saulnier, D., Haffner, P., Goarant, C., Levy, P., Ansquer, D., 2000. Experimental infection models for shrimp vibriosis studies: a review. Aquaculture. 191, 133-144.

Shpigel, M., Barber, B. J., Mann, R., 1992. Effects of elevated temperature on growth, gametogenesis, physiology, and biochemical composition in diploid and triploid Pacific oysters, Crassostrea gigas Thunberg. J. Exp. Mar. Biol. Ecol. 161, 15.

Soletchnik, P., Lambert, C., Costil, K., 2005. Summer mortality of Crassostrea gigas (Thunberg) in relation to environmental rearing conditions. J. Shellfish Res. 4, $197-$ 207.

Soletchnik, P., Le Moine, O., Faury, N., Razet, D., Geairon, P., Goulletquer, P., 1999. Summer mortality of the oyster in the Bay Marennes-Oléron: Spatial variability of environment and biology using a geographical information system (GIS). Aquat. Living Resour. 12, 131-143.

Soletchnik, P., Razet, D., Geairon, P., Faury, N., Goulletquer, P., 1997. Ecophysiologie de la maturation sexuelle et de la ponte de l'huître creuse Crassostrea gigas: réponses métaboliques (respiration) et alimentaires (filtration, absorption) en fonction des différents stades de maturation. Aquat. Living Resour. 10, 177-185.

Soletchnik, P., Ropert, M., Mazurie, J., Fleury, P. G., Le Coz, F., 2007. Relationships between oyster mortality patterns and environmental data from monitoring databases along the coasts of France. Aquaculture. 271, 384-400.

Stearns, S. C., 1976. Life-history tactics: A review of the ideas. Q. Rev. Biol. 51, 3-47.

Thompson, F. L., Austin, B., Swings, J., 2006. The biology of Vibrios. American Society for Microbiology Press, Washington, D. C. 
979 Tran, D., Massabuau, J.-C., Vercelli, C., 2008. Influence of sex and spawning status on 980 oxygen consumption and blood oxygenation status in oysters Crassostrea gigas cultured in a Mediterranean lagoon (Thau, France). Aquaculture. 277, 58.

982 Travers, M.-A., Basuyaux, O., Le Goic, N., Huchette, S., Nicolas, J.-L., Koken, M., Paillard, 983 C., 2008. Influence of temperature and spawning effort on Haliotis tuberculata 984 mortalities caused by Vibrio harveyi: an example of emerging vibriosis linked to global warming. Glob. Chang. Biol. 15, 1365-1376.

986 Travis, J., Potempa, J., Maeda, H., 1995. Are bacterial proteinases pathogenic factors? Trends 987 Microbiol. 3, 405-407.

Van der Meer, J., 2006. An introduction to Dynamic Energy Budget (DEB) models with 990 special emphasis on parameter estimation. J. Sea Res. 56, 85.

991

Wang, Z., Guo, X., Allen, S. K., Wang, R., 2002. Heterozygosity and body size in triploid 992 Pacific oysters, Crassostrea gigas Thunberg, produced from meiosis II inhibition and 993 994 995 996 
998 Table 1

999 Characteristics of experimental infection challenges (infection date, injected dose, number of 1000 animals transferred to the infection room). CFU: Colony Forming Unit, SASW: Sterile 1001 Artificial Sea Water.

1002

\begin{tabular}{ccccc} 
Infection & Injected dose & \multicolumn{3}{c}{ Number of animals injected } \\
\cline { 3 - 5 } & (CFU/ind.) & 2n & 3nDT & 3nCB \\
\hline A & $10^{7}$ & 63 & 53 & \\
10-May-07 & $10^{6}$ & 62 & 54 & not tested \\
& SASW & 26 & 32 & \\
\hline \multirow{2}{*}{ B } & $10^{7}$ & 48 & 49 & 48 \\
26-Jun-07 & $10^{6}$ & 48 & 49 & 49 \\
\hline \multirow{2}{*}{ C } & SASW & 20 & 20 & 20 \\
29-Aug-07 & $10^{7}$ & 60 & 60 & 56 \\
& $10^{6}$ & 61 & 63 & 59 \\
\hline \multirow{2}{*}{ D } & SASW & 20 & 20 & 20 \\
\hline 21-Jan-08 & $10^{7}$ & 69 & 68 & 42 \\
\hline
\end{tabular}

1003

1004 


\section{Table 2}

1007 Reproductive scale for Crassostrea gigas based on Mann (1979) and Lango-Reynoso et al. 1008 (2000).

1009

Stage

0 (resting stage)

$\longrightarrow$

1 (early growth stage)

2 (late growth stage)

Follicles are actively developing with primary gametocytes

3 (mature) and some free (secondary) spermatozoa and oocytes

Near ripe or ripe follicles, densely packed with maturing

\section{Histological description}

No trace of sexual development; follicles are non-existent or elongated and consist of undifferentiated germinal epithelium

Follicles are small and isolated with numerous spermatogonia or oogonia

gametes; presence of mature gametes

4 (spawning and reabsorption stages) $\quad$ Follicles distended, numerous gametes remain

1010

1011

1012

1013 
1014

1015 Table 3

1016 Cox regression model results using the TPHREG procedure.

1017

\begin{tabular}{cccc}
\hline Variables & DDL & $\chi^{2}$ & $\operatorname{Pr}>\chi^{2}$ \\
\hline Date & 3 & 10.24 & 0.017 \\
Group & 2 & 6.17 & 0.046 \\
Treatment & 1 & 50.77 & $<.0001$ \\
Date $\times$ Group & 5 & 11.44 & 0.043 \\
Date $\times$ Treatment & 3 & 8.68 & 0.034
\end{tabular}

Results of the contrast statement

$\begin{array}{cccc}2 \mathrm{n} \text { vs } 3 \mathrm{n} & 1 & 6.12 & 0.013 \\ 3 \mathrm{nCB} \text { vs } 3 \mathrm{nDT} & 1 & 0.22 & 0.640\end{array}$

1018

1019

1020

1021

1022 
1024 A. Mean ( \pm SE) survival rates (\%) obtained 13 days post-infection after $40 \mathrm{~h}$ exposure to $V$. splendidus LGP32-GFP and V. aestuarianus 02/041 strains by bath immersion. Results are

1026 given according to the reproductive status of the tested oysters. A $\chi^{2}$ test was performed to analyse significant differences of survival rates obtained after bath challenge.

B. $\quad V$. splendidus LGP32-GFP mutated strain infecting Crassostrea gigas. Immunohistochemical analysis of $(1,2,3,4,6,7,8)$ gonadic tissue, $(5,11)$ adductor muscle and $(9,10)$ conjunctive tissue of oysters that had died during the 7 days following the $40 \mathrm{~h}$ exposure to $V$. splendidus LGP32 and $V$. aestuarianus $02 / 041$ strains by bath immersion.

Fig. 2

1034

A. Variation in proportion of sexual maturity stages for diploid individuals tested at the four Vibrio injection challenges (A, B, C, D) using the reproductive scale for Crassostrea gigas based on Mann (1979) and Lango-Reynoso et al. (2000) (see Table 1).

B. Mean gonadic occupation (GO \%) measurements $( \pm \mathrm{SE})$ made on $2 \mathrm{n}, 3 \mathrm{nDT}$ and $3 \mathrm{nCB}$ individuals tested at the four Vibrio injection challenges (A, B, C, D). Different letters indicate significant differences among and within groups (ANOVA, $\mathrm{p}<0.001$ ). $\rightarrow$ t" means not tested".

Fig. 3

1043 Kaplan-Meier estimate of the survival distribution function obtained each day in the three tanks used per treatment, for the three groups injected with the two injection doses. The lower dose is represented by a dotted line ( ... ), the higher dose ( - ) by a solid line.

\section{Fig. 4}

1048 Mean ( \pm SE) survival times calculated from the Kaplan-Meier survival distribution functions 1049 in the three tanks used per date (A, B, C, D) for the three groups, $2 \mathrm{n}, 3 \mathrm{nDT}$ and $3 \mathrm{nCB}$, 1050 injected with the lower dose (A) and the higher dose (B) of Vibrio strains. $\rightarrow$ t" means fot 1051 tested". Comparisons between survival curves were performed for each dose with the 1052 Wilcoxon test: $i$. the equivalence between the survival curves among groups at a common 1053 infection date is represented by Arabic numerals, ii. the equivalence between the survival 1054 curves within groups (each group separately, $2 \mathrm{n}, 3 \mathrm{nDT}$ or $3 \mathrm{nCB}$ ) is represented by letters. 
1056

1057 Fig. 1 A

1058

1059

1060

1061

1062

1063

1064

1065

1066

1067

1068

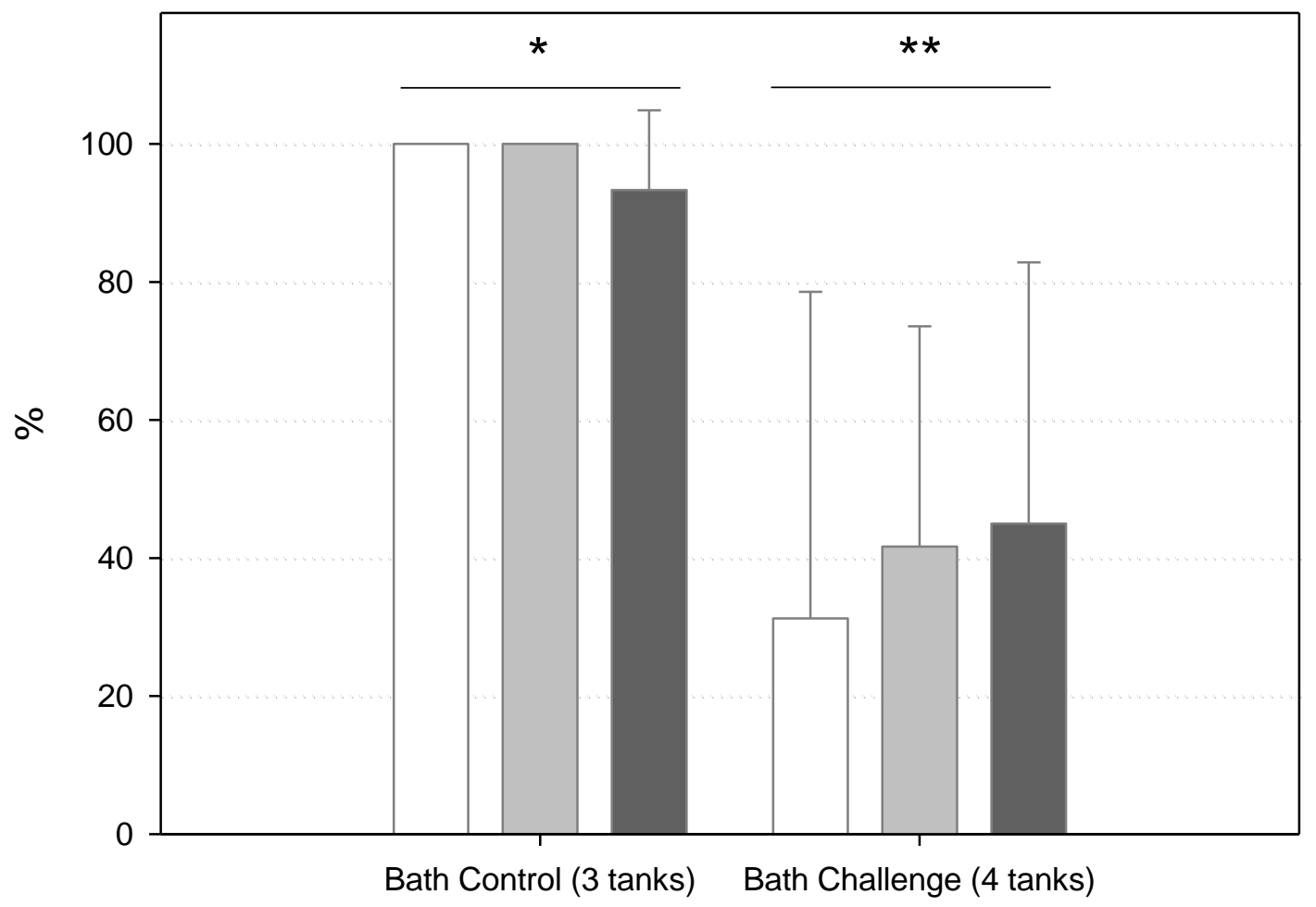

1069

Spawning ind.

Mature but non spawning ind.

Non mature ind.

1070

1071 
1072

1073 Fig. 1 B

1074

1075

1076

1077

1078

1079

1080

1081

1082

1083

1084

1085

1086

1087

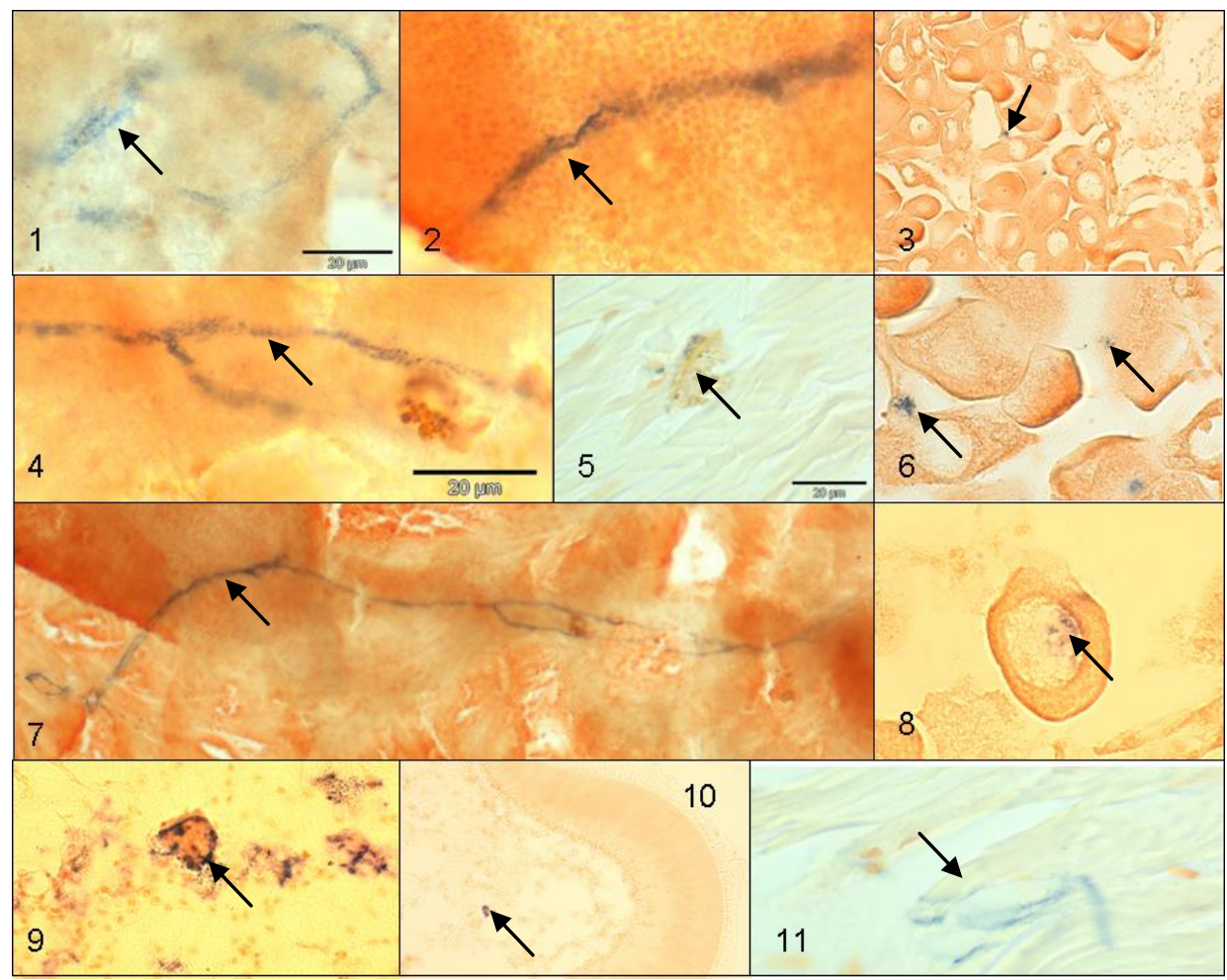

1088

1089 
1090

1091 Fig. 2 A

1092

1093

1094

1095

1096

1097

1098

1099

1100

1101

1102

1103

1104

1105

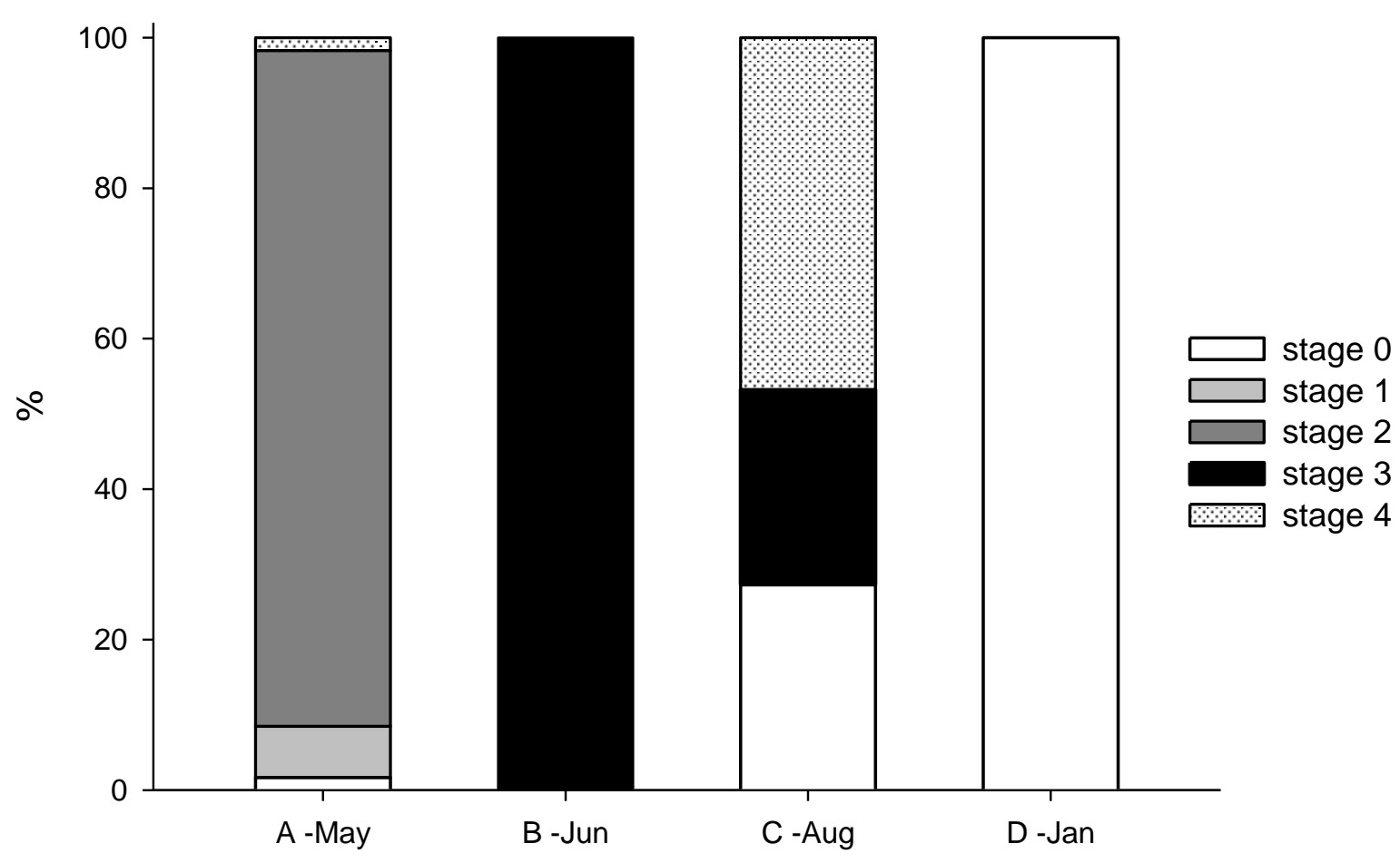

1106

1107 
1108

1109 Fig. 2 B

1110

1111

1112

1113

1114

1115

1116

1117

1118

1119

1120

1121

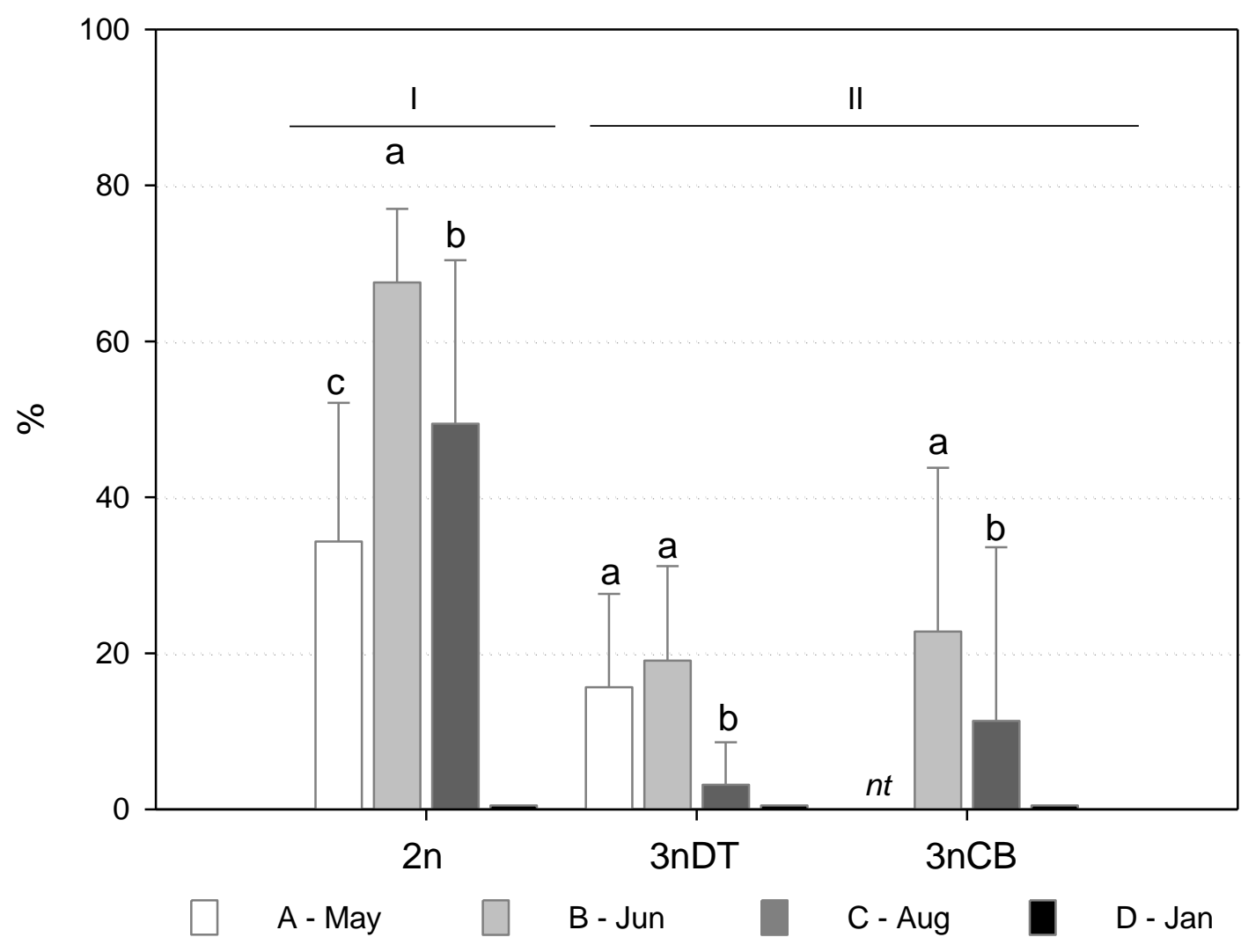

1122

1123

1124 
1125 Fig. 3

1126

1127

1128

1129

1130

1131
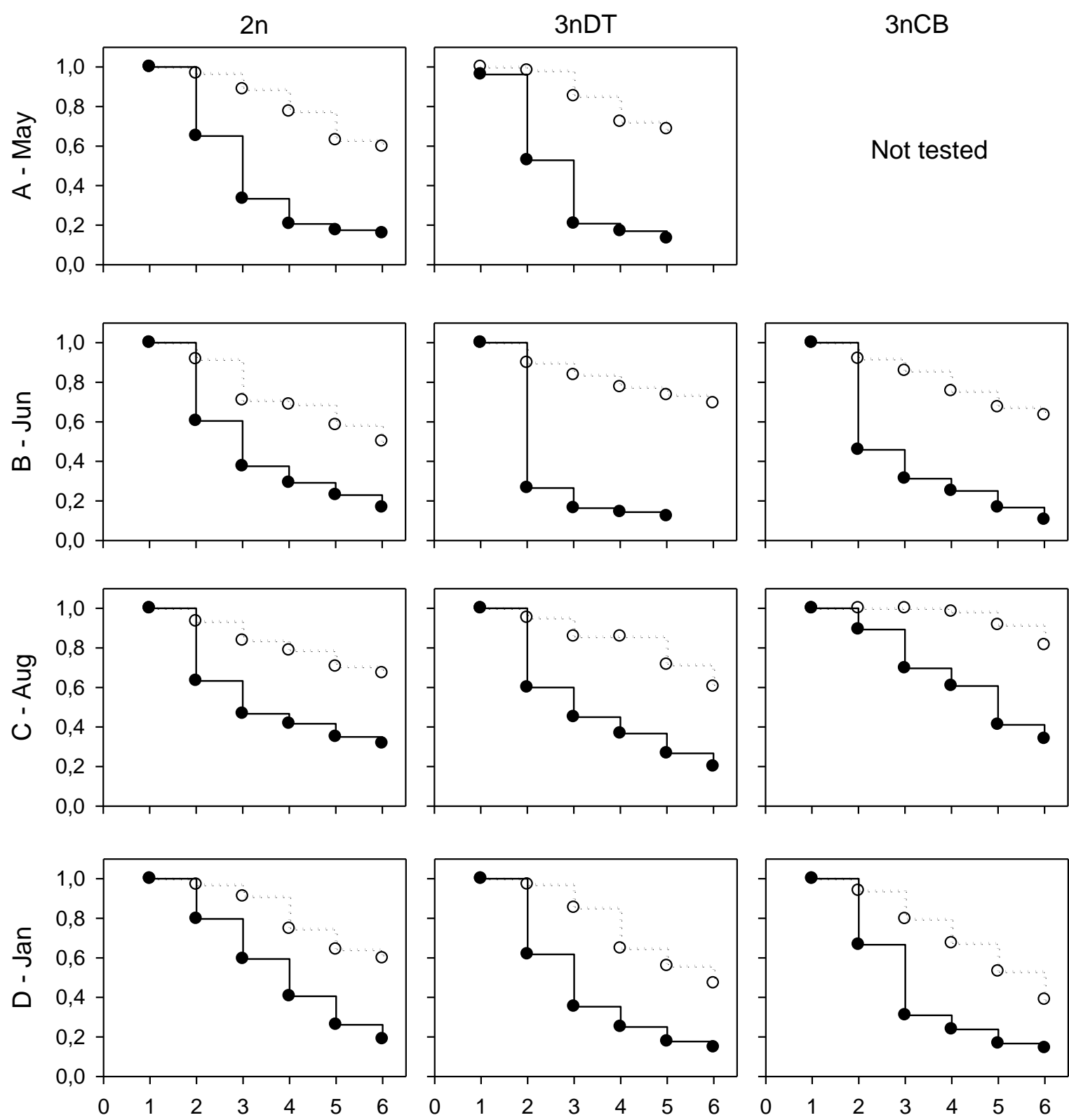

1132

Day post-injection

1133 
1134

1135 Fig. 4 A

1136

1137

1138

1139

1140

1141

1142

1143

1144

1145

1146

1147

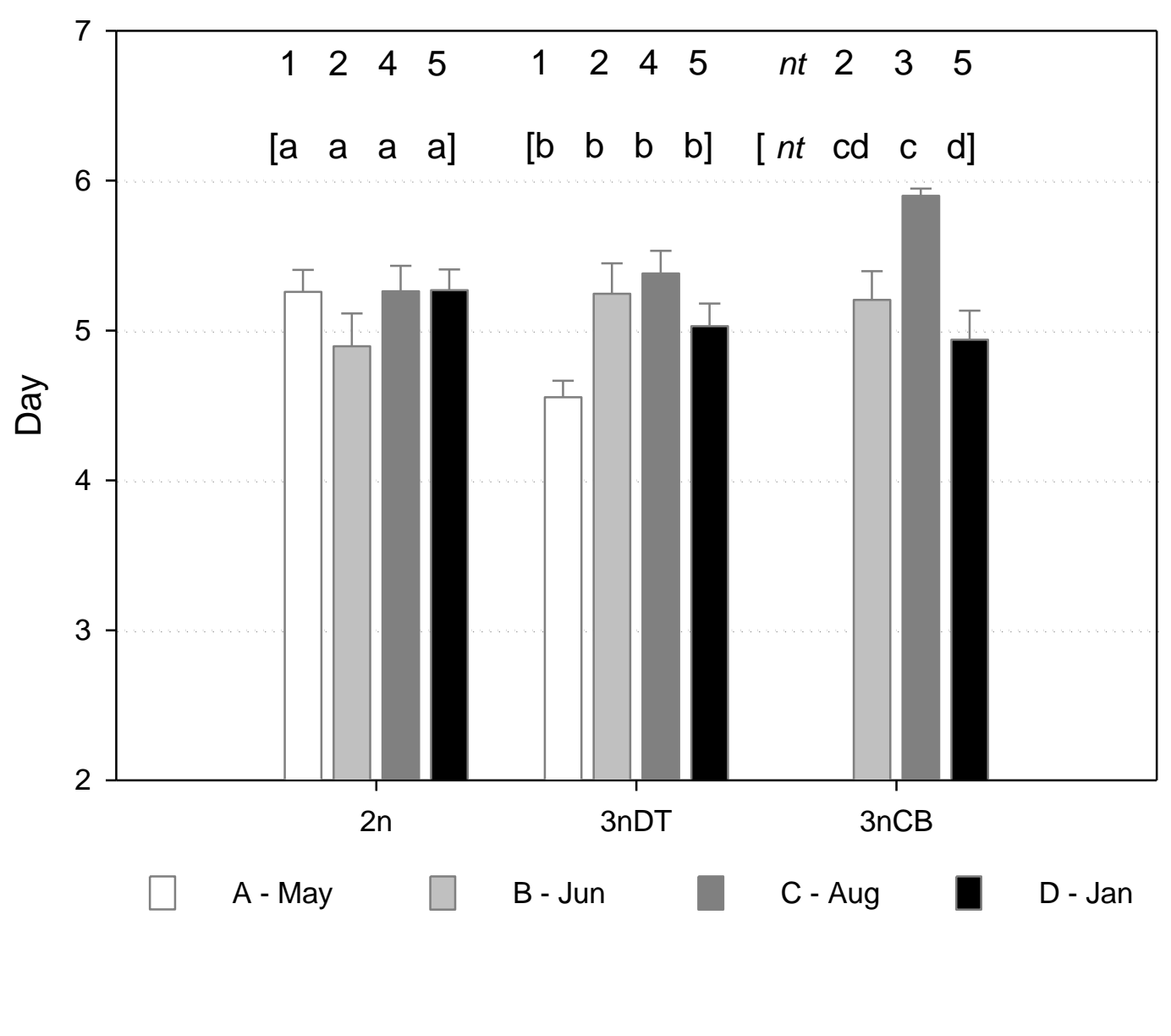


1151 Fig. 4 B

1152

1153

1154

1155

1156

1157

1158

1159

1160

1161

1162

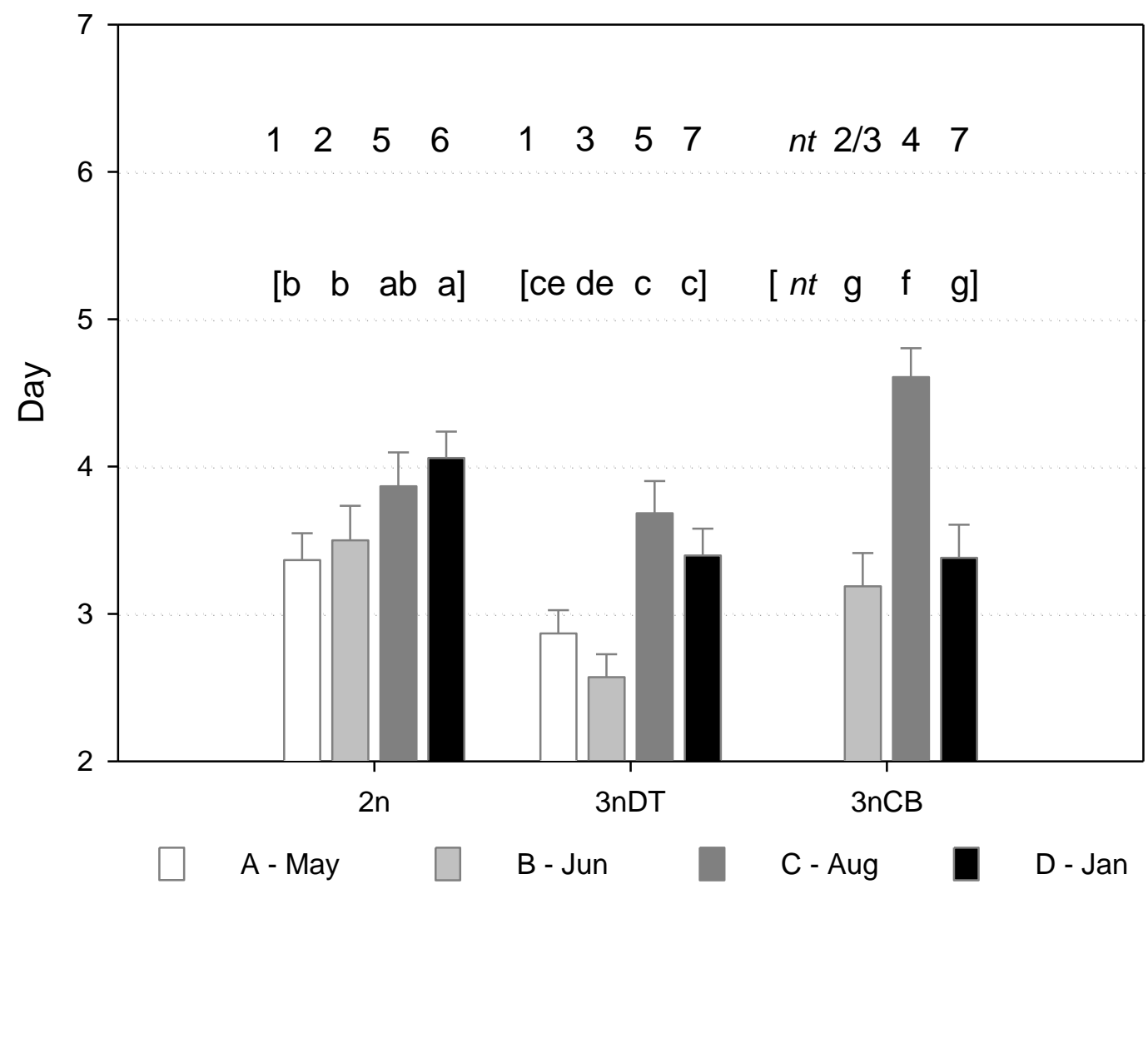

